\title{
LIVING LABS AS A PEDAGOGICAL TEACHING TOOL FOR GREEN BUILDING DESIGN AND CONSTRUCTION IN HOT ARID REGIONS \\ DOI: http://dx.doi.org/10.26687/archnet-ijar.v12i1.1285
}

\author{
Marwa Dabaieh*, Deena El Mahdy, Dalya Maguid
}

\section{Keywords}

learning by doing; action research; living lab; arid climate; low impact design

ArchNet-IJAR is indexed and listed in several databases, including:

- Avery Index to Architectural Periodicals

- EBSCO-Current Abstracts-Art and Architecture

- CNKI: China National Knowledge Infrastructure

- DOAJ: Directory of Open Access Journals

- Pro-Quest

- Scopus-Elsevier

- Web of Science

\section{Abstract}

Sustainability and environmental illiteracy is still common in architectural curricula for undergraduate education. This may lead to further generations of architects who are unequipped for global sustainability goals. This paper discusses a living lab teaching experience which investigates the roles of learning through doing and hands-on building experimentation to root an understanding of sustainability in architectural education. The design studio at the centre of this paper was focused on passive, low-cost and energyefficient approaches suitable for a hot arid climate. The students were asked to design a refugee shelter prototype that was cost- and time-efficient, that would also present the least impact on the environment after demolition. The course's teaching process also included invited guest speakers, field trips and a hands-on workshop for low-tech building techniques as a prelude to designing and building a full-scale physical model. Thermal comfort and energy consumption for the design proposal were evaluated by simulation, and the physical model was evaluated by field monitoring. This paper outlines the design studio pedagogical experimental living lab process and the resulting students' projects. It also shows the various skills the students acquired and suggests how this type of pedagogy can be viewed as a pilot model for green architecture education.

\footnotetext{
M.Dabaieh ${ }^{1^{*}}$

Malmö University, Nordenskiöldsgatan 1, Malmö 2506 ,Sweden

D. El Mahdy ${ }^{2}$ \& D. Maguid ${ }^{2}$

British University in Egypt, El Sherouk- Suez Desert Road, Cairo and 11837, Egypt
} 


\section{INTRODUCTION AND LITERATURE OVERVIEW}

Given the growing energy crisis worldwide, the application of sustainability methods within the built environment has become essential for many countries, particularly those in the Middle East. This is especially important in light of the worldwide increase in rates of energy consumption and the depletion of energy resources. According to IPCC (2017), buildings account for almost half of global energy consumption (Beck and Mahony, 2017), while on the regional level in the Middle East, the building sector alone accounts for about $40 \%$ of the region's total energy consumption (RCREEE, 2013). Similarly, in Egypt, residential buildings account for about $47 \%$ of the country's energy consumption, followed by industrial buildings at $20 \%$ (EEHC, 2011; Shaaban \& Badr, 2013). As a result, a growing demand for more sustainable green buildings and the need for low or zero carbon cities has arisen, but implementing holistic sustainable design approaches requires well-trained professionals and architects (Gucyeter, 2016). Many architectural programmes worldwide have begun to integrate sustainable concepts into their educational programmes; however, programme inconsistencies and the lack of thorough integration persist (Lidgren et al., 2006). Furthermore, no clear pedagogy for fully integrating sustainable environmental design within architectural curricula is currently in place (Altomonte, 2009). Thus, the integration of energy efficiency methods and environmental awareness in architectural education curricula is highly important.

Parallel to the growing global interest in efficient energy use and concern for natural resources, green building design and sustainable technology have gradually become primary to the education of architectural students (Lee and Huang, 2011). Despite all the advances in the architecture green design movement, architectural educators are still struggling to cope with mounting ecological challenges by preparing students to meet the current toll on the environment (Guzowski, 2010). There is no doubt that many instructors are fully aware and now accept that it is important to introduce climate-responsive design to their students, and they try to raise their awareness about current and future climate challenges at both the urban and architectural levels (Lenzholzer and Brown, 2013). Other educators offer a different approach and suggest establishing new curricula with a focus on sustainable development and its direct and indirect impact on culture and society (Al-Hagla, 2012). Looking at current practices, there are theoretical and practical courses that cover sustainability issues and introduce green design into architectural education (Taleghani et al., 2010) and the construction of green buildings (Taleghani et al., 2011). Still, there are a few emerging green design studios, such as those offering carbon neutral design, a concept which is yet to be quite defined and articulated for architectural education (La Roche, 2017).

Linking lessons learned from vernacular design for green and sustainable building is still limited and is normally confined to vernacular aesthetics, and its perceived social and cultural connections (Dabaieh, 2015). A few specialised courses at undergraduate or graduate level exist on sustainability and vernacular architecture; examples are the Masters courses at Oxford Brookes University (UK) and Florida University (US). On the other hand, international projects have been established trying to help to bridge the gap between sustainability as a practice and green architectural methodologies in education. For example, EDUCATE (Altomonte et al., 2014) and EduCamp (Sewilam et al., 2015) are projects that target sustainable development and education.

One interesting approach has been to promote using green buildings as teaching tools for sustainability (Cole, 2014). Such methods prove that by building green we can ensure a healthy and pleasing environment for building users which at the same time serve as real-life 
examples for educational practice and learning (Hoffman, 2009). Other research work has followed similar concepts by combining pedagogical models with potential design criteria of architectural space (Vargas, 2016). Game Based Learning (GBL) is another recently adopted tool to improve green building education (Juan and Chao, 2015) with the aim of reducing the gap between education and practice. Reinhart et al. (2012) used GBL to connect building energy modelling and simulation with green education for teaching energy efficient building practice through a class game exercise.

While the architectural profession in the Middle East has changed considerably recently, the educational process remains slow to respond. In Egypt, although environmental awareness in sustainable design education began more than twenty years ago for both postgraduate and undergraduate architectural curricula, ecologic illiteracy continues to exist in architecture education and architecture practice (Dabaieh \& Nour, 2013). Today, a yawning gap remains between what schools of architecture offer, what the regulations currently specify, and what the market demands (Dabaieh et al., 2017). Previous research suggests that many of the problems found in the built environment today originate from problems within the current architectural education systems (Dabaieh et al., 2017). These problems include a gap between research and practice as well as the gap between education and practice (Farahat, 2011). Furthermore, Dessouky (2016) also identified a gap in the integration of environmental and societal needs within both architectural practice and educational programmes. Consequently, many students are unable to deal with the realities of professional practice after they graduate (Dabaieh et al., 2017; Farahat, 2011).

A few, but still somewhat limited, serious attempts exist at the local level calling for change in architectural teaching in Egypt (Gaber and Al-lbrashy, 2010). Despite these, it remains a fact that there is a serious gap between what is taught in the architecture schools and the current demand for green building in the local Egyptian building market and real estate sector (Dabaieh and Nour, 2013; Samir ElSawy and Safey EIDeen, 2014). Educators such as Salama (2009 \& 2010) also highlight the need for education to be more responsive towards contemporary social demand. After analysing 14 programmes in eight Middle Eastern countries, Salama and Amir (2005) conclude that there is an issue with the integration of aspects related to contextual urban and rural development in the curricula. Furthermore, their analysis points out that the courses in these programmes focus mainly on aesthetics, history and theory rather than on the social needs, and the cultural and socio-economic issues that are relevant to a country's local environment (Salama \& Amir, 2005). Dessouky (2016), too, asserts the need to address social and environmental issues within architectural education and to make a shift from a theoretical perspective to actual implementation. Another proponent of change is Salama, who has proposed a revolution in the teaching and learning techniques used in architecture education (Salama, 2010; 2015). He offers alternative methods of teaching, for example the use of design studios as the main forum for students' interaction and imaginative exploration, as a way of promoting creative knowledge gain, integration, and reproduction. He also compares real-life examples and advances in design approaches and methods using critical inquiry, process-based learning, community design and community build live project studios.

Research that addresses undergraduate architectural pedagogy at universities in Egypt is still lacking. However, this type of research is particularly important to allow for the continuous development of programmes within the region. Nevertheless, previous existing studies have also called for a shift from traditional teaching methods in Egyptian architectural programmes to more experiential learning approaches where students are active participants and not mere spectators (Dabaieh et al., 2017). Based on the above, an undergraduate 
senior elective course for the architecture of arid environments offered during spring 2016 semester was chosen as a pilot case for this study of experiential current learning approaches. The course was divided into three phases and included both theoretical and hands-on experimentation in a campus living lab environment. The main objective of the course was to teach students the fundamentals of best practice and design for hot, arid environments, focusing on the Egyptian context. The main teaching philosophy applied in this course was learning by doing and experimenting in an actual urban living lab. During the 15 weeks of the course, the students were introduced to passive vernacular solutions and environmentally conscious strategies, together with the environmentally friendly natural materials used during construction. The lectures began with targeted discussions about various environmental movements and the increased awareness among architects that followed the energy crises of the 1970s, and then moved on to modern architecture movements, contemporary design and the construction of smart buildings. The teaching approach was based on case studies that illustrate not only construction methods but the application of different theoretical principles for building physics, material thermal behaviour and properties. The course was designed so that six weeks covered theory followed by four weeks for a design and design development exercise for a passive and low-cost refugee shelter. The final five weeks were given over to the implementation of a full-scale shelter model. The seventh week included field trips to view projects that applied passive and lowenergy design methods in Egypt using low-tech construction approaches. The trips inspired the students, which made it easy for them to relate what they saw to the theoretical knowledge taught in class. A total of 18 students were divided into two teams working as competitive groups along the different phases of the course.

This paper discusses the pedagogical process and shows the outcomes of the students' building prototypes, an assessment of the students' work, and the students' feedback on the overall learning experience for the arid environment course. It is argued that traditional teaching methods lack the use of the interactive learning that helps students understand the multiple dimensions of the built environment (Salama, 2010). Moreover, the importance of both in-class and off-campus active, experiential learning is nothing new (Salama, 2010). It is an aspect that is directly related to the hands-on pedagogy proposed in this paper. The hope is that the methodology of this course will inspire and can be feasibly applied in a large number of architectural courses, resulting in a new generation of architects who can compete with the challenges and wicked problems of climate change within the built environment.

\section{COURSE METHODOLOGY}

The methodology adopted in this pilot course is learning by experimentation in an urban living lab environment. Several tools and techniques were used in the course during the three main phases mapped in Figure 1. 


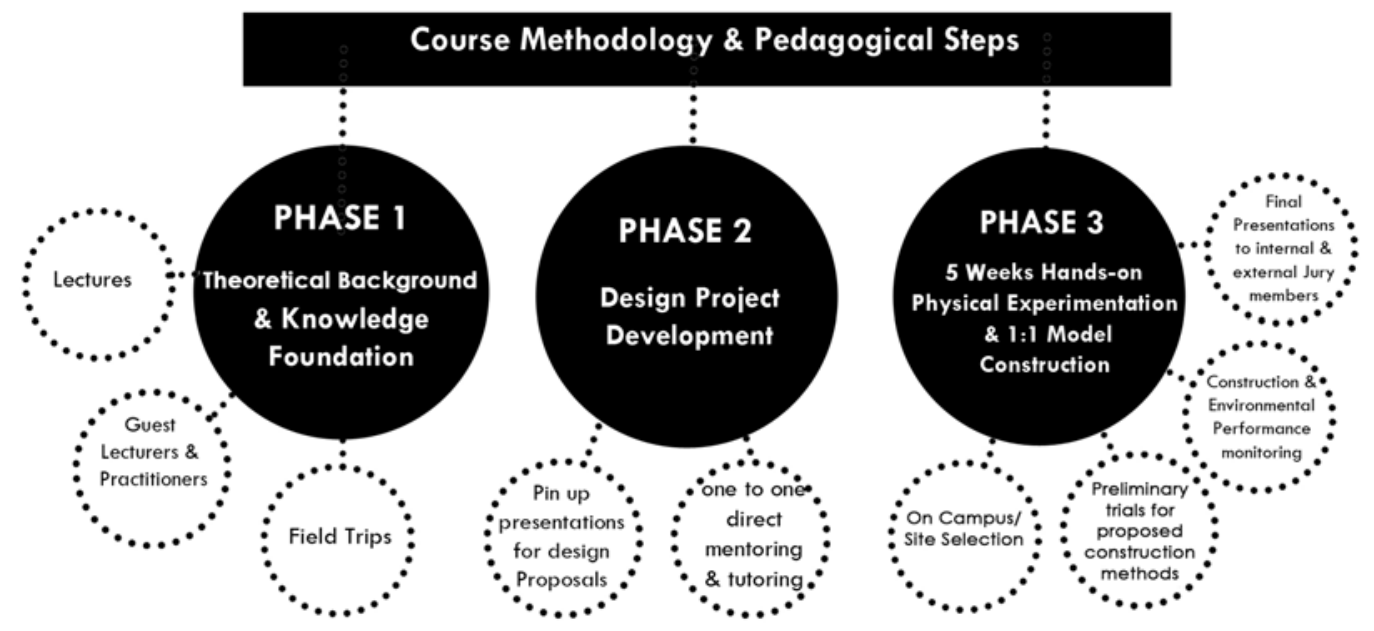

Figure 1: Pedagogical process for the course and methodology used during the three phases (Source: Authors).

\section{Phase One: Theoretical Base and Learning by Exploring}

\section{Lectures and Guest Speakers}

During the first six weeks and in a classroom environment, the students were introduced to the main theoretical background and the key facts of the current energy problems in Egypt. They were also introduced to Egypt's status quo compared to the rest of the world in terms of $\mathrm{CO}^{2}$ emissions per capita. This introduced the principles of passive and climatic-responsive architecture with a focus on hot and arid environments. The main strategy was to examine the lessons learned from vernacular architecture in Egypt and other countries in the same climatic zone. The main topics discussed included examples of vernacular architecture in hot arid regions, passive design standards for hot arid climates, passive solar urban design, passive solar landscape, thermal zoning strategies and building envelope strategies. Passive heating and cooling strategies were also discussed, in addition to shading, natural daylight and ventilation. Lectures were supported by invited guest speakers who were researchers, academics and practising architects, which acted as the main supporting teaching tool at the beginning of the course.

\section{Field Trip}

A field trip was also organised to Nuweiba city in Egypt's South Sinai, during which student focus-group discussions and self-reflection on the materials taught in class took place. During the field trip, there were several guided tours with experts and owners of various ecolodges, such as the Basata eco-lodge, that has been built using sustainable materials such as reeds, stone, palm wood and mud bricks. That allowed the students to see real-life examples of a successful eco-friendly design. The Basata eco-lodge owner, who was himself an engineer practitioner, explained in detail the environmentally friendly and climate adaptive approaches that had been applied in the design and construction of the eco-lodge. As the area is a Natural Protectorate, he showed the students how the environmental impact assessment had been applied in practice. The owner also explained to them the concept of a circular economy, according to which he was running this business by empowering the local 
Bedouins and encouraging them to become an integral part of the project. He showed them how the eco-lodge served the indigenous society both directly and indirectly as one of the main objectives is to build a school to educate the Bedouins, who cannot afford to travel long distances to the nearest school. The students also visited the Habiba recycling factory and organic farm, which gave them an insight into the processes involved in sorting waste and recycling, and how various recycled materials such as plastic and glass bottles can be reused in construction. This visit was an eye opener and a source of inspiration just by looking at the whole sustainable life cycle: Habiba Organic Farm, which is a private organisation, is self-sustaining and operates a closed waste cycle by the re-use and upcycling of waste materials. At the end of the field trip, a hands-on building exercise was conducted at Habiba Farm, where the students got the opportunity to participate in building part of a clay wall using the cob technique. Furthermore, the field trip included a visit to the local Bedouin communities to get an insight into the indigenous life style and the vernacular solutions to achieve acclimatisation using low tech solutions. At the end of the trip, they visited Nuweiba's new development harbour area to see the plans for the area's future, after which there was an on-site discussion on the potential influence of such project on the cultural, economic, environmental and social aspects of sustainable development.
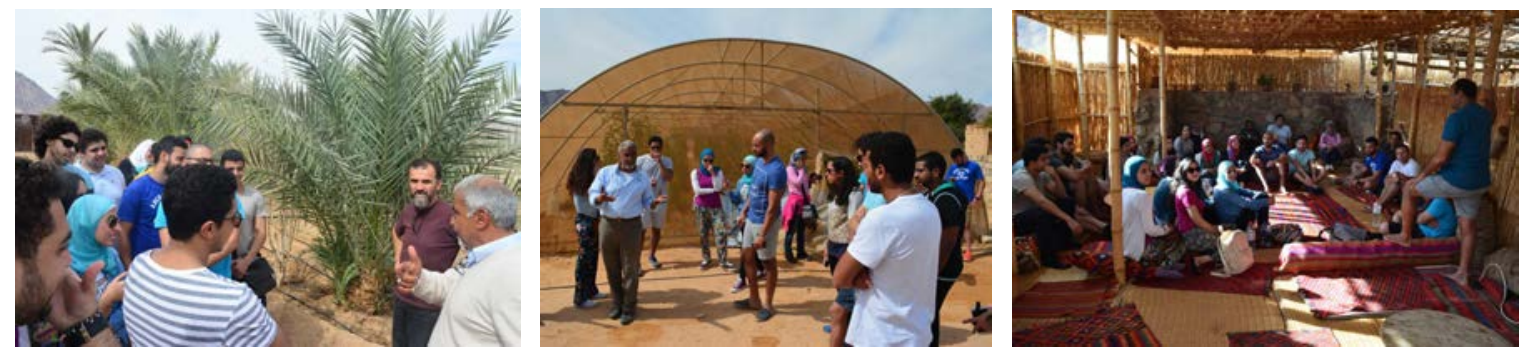

Figure 2: The students during the field trip visiting different eco-lodges in Nuweiba (Source: Authors).

At the end of phase one, the students were given their assignment to design and build a $12 \mathrm{~m}^{2}$ substantial refugee shelter. The assignment entailed three main components:

- Research and analysis of previous examples of passive and climatically conscious refugee shelters in hot arid climates.

- A detailed design proposal for a low cost and low-tech Do It Yourself (DIY) passive refugee shelter prototype.

- A 1:1 implementation of the refugee shelter prototype design in full scale on return to the university campus.

\section{Phase Two: Students' Project Design and Design Development}

Phase two consisted of four weeks of tutoring while the students developed their project design concepts with the help of two teaching assistants who help them with literature materials, resources, feedback and feedforward on their design development. The lectures began with pin-up group presentations for the design proposals followed by one to one direct mentoring and tutoring explained in detail below. 


\section{Pin up Group Presentations for Design Proposal}

For this stage, the students used the theoretical knowledge they had gained from lectures and practical applications they had observed during the field trip. They supported this with their own fresh research on similar projects and case studies. After two weeks, they were expected to present their preliminary research on the materials, the construction methods they proposed and the passive design strategies they planned to apply. This was followed by a step-by-step design process, which also entailed detailed technical drawings and calculations for $U$ values, thermal performance and cost efficiency calculations for the materials suggested. At the end of this phase they used simple software such as Climate Consultant, the Autodesk Green Building Studio and Passive Assistant Tool to run some modelling and simulation to verify the climatic responsive and passive design approaches proposed.
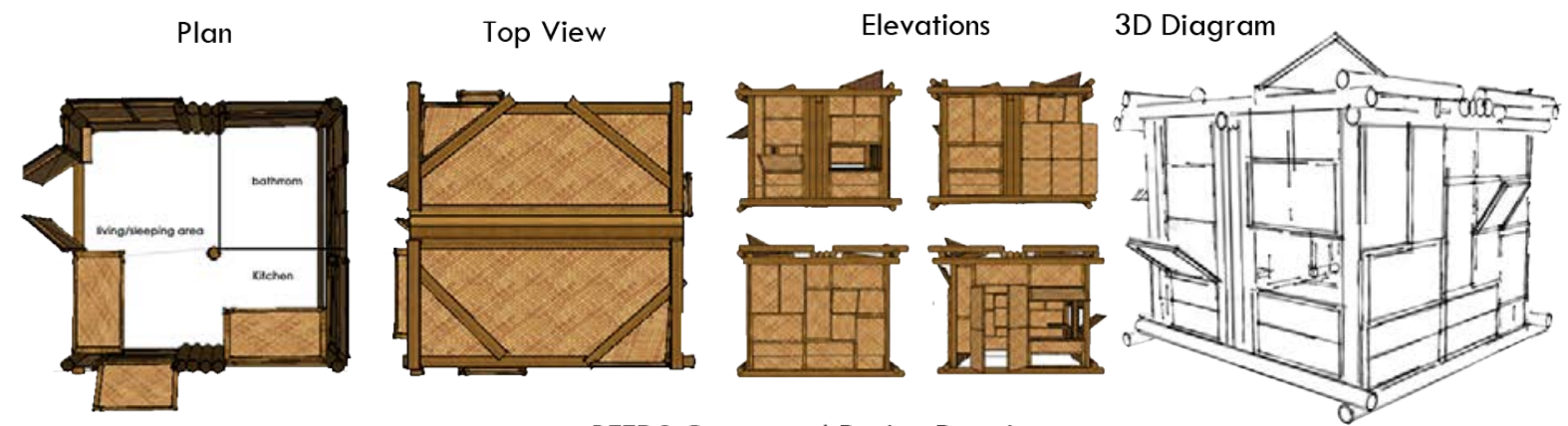

REEDS Conceptual Design Drawings

Figure 3: Extract from group one's drawings for the design development phase' (Source: Reeds Group Student Report, 2015)
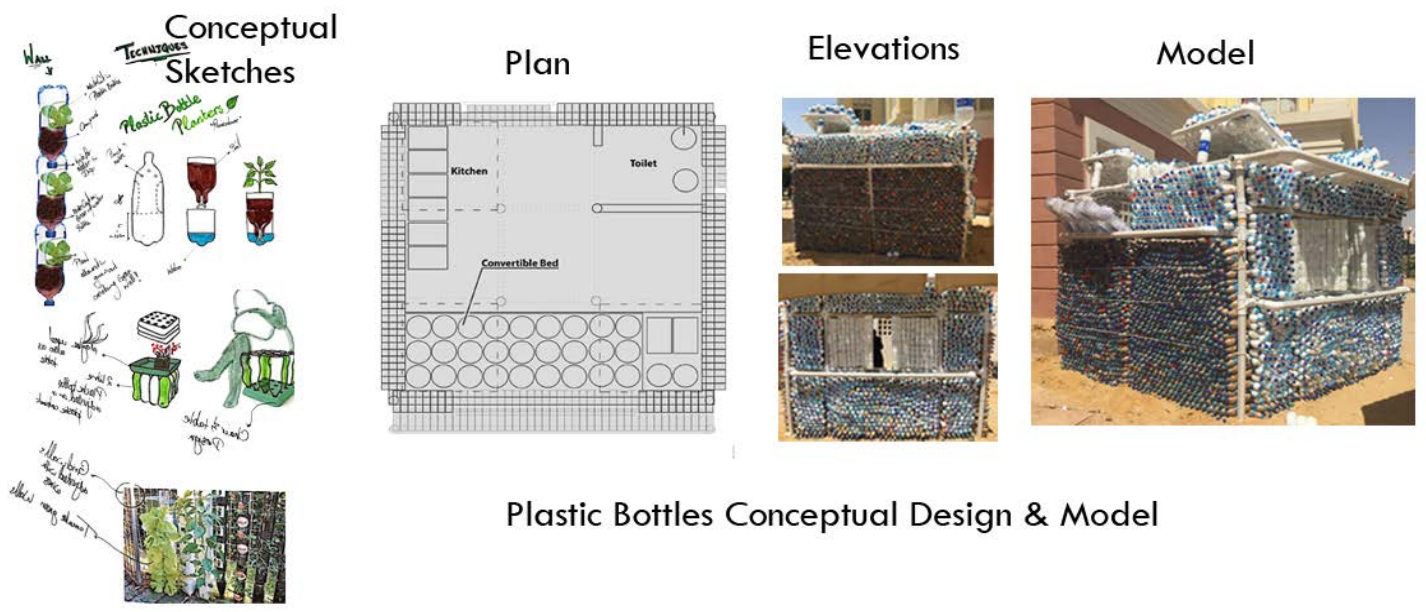

Plastic Bottles Conceptual Design \& Model

Figure 4: Extract from group two's drawings for the design development phase' (Source: Plastic Bottles Group Student Report, 2015) 


\section{One to One Direct Mentoring and Tutoring}

Direct one to one mentoring and tutoring took place over three weeks for the design proposals development process. During that time, the students were coached on how to design technical installations for water and drainage systems using low-tech ecological solutions and to make a simple budget analysis for the total cost of their prototypes. They were also given direct feedback on construction material suggestions, load bearing calculations and how to prepare for the construction process during physical building implementation on campus. Several discussions took place on health and safety and first aid, as well as discussions on materials transport to campus and site management. The students were advised how to handle storing the materials and managing the construction phases smoothly. Time planning was another essential part of the discussion as they were afraid that the implementation part would be time consuming as this was their first time building something to full scale. There were also worried whether they could deliver the final project to schedule if something went wrong and they had to re-do part of the structure.

\section{Phase Three: Physical Experimentation 1:1 Prototype and Evaluation}

\section{Part one (material and site selection)}

A selected site was chosen on campus for the building of the two prototypes and the two groups decided which location was best suited for the physical shelter model they planned. This step was important training as they needed to observe the local site micro-climate and look for the proper building orientation, wind direction, movement of the sun and any shade thrown by neighbouring buildings that might affect their model performance. The students themselves brought the materials and tools needed to construct the shelter and stored them on site. The students in both groups went through several preliminary, trial-and-error tests for the construction methods they proposed. Group one settled on plastic bottles of different sizes, the other group on reeds and baby bamboo. After the materials had been selected for both shelters, the groups made several on-site changes and improvements to some of their ideas. Health and safety precautions were followed during the implementation phases.

\section{Part two (construction and environmental performance monitoring)}

The students began with the main structural elements for the foundations and wall supports before moving on to the roof structure. They developed on site several joints and fixation methods that were both low-tech and strong enough to carry loads. They started actual building with the wall construction as infill for the main structure system. There were differences in the structure design between the two groups depending on the materials used. During the construction process, the two groups would consult each other on how to fix issues with their prototypes and helped each other at other times. They shared tools instead of buying the same tools twice. Although the groups were in competition their group work and team spirit were important. As tutors, observation of the students indicated how useful it was to exchange experience in this manner about different materials and construction methods. They also developed strong ties of friendship by spending so long working together, and having fun singing and joking when things went wrong. When the deadline was approaching, they asked other junior students to help them, which gave an opportunity for the juniors to be exposed to this type of building experience. When the construction was complete, the students carried out simple on site tests to check safety and structure stability. That was 
essential to ensure that their prototypes could stand up to wind and were sufficiently stable to be used for demonstration purposes with no hazards on campus. The two prototypes were monitored for 24 hours to measure indoor temperature and humidity compared to outdoor values. The purpose of this exercise was to assess and compare the performance of both prototypes in relation to the standard Egyptian average indoor comfort limits. The process of the physical model is explained in figures 5 and 6.

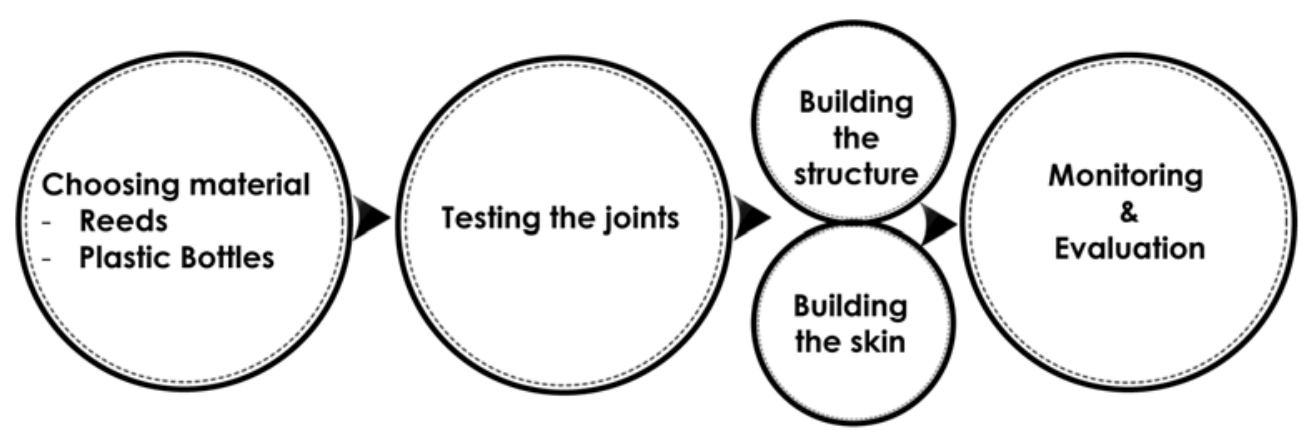

Figure 5: The physical model from design to implementation (Source: Authors).
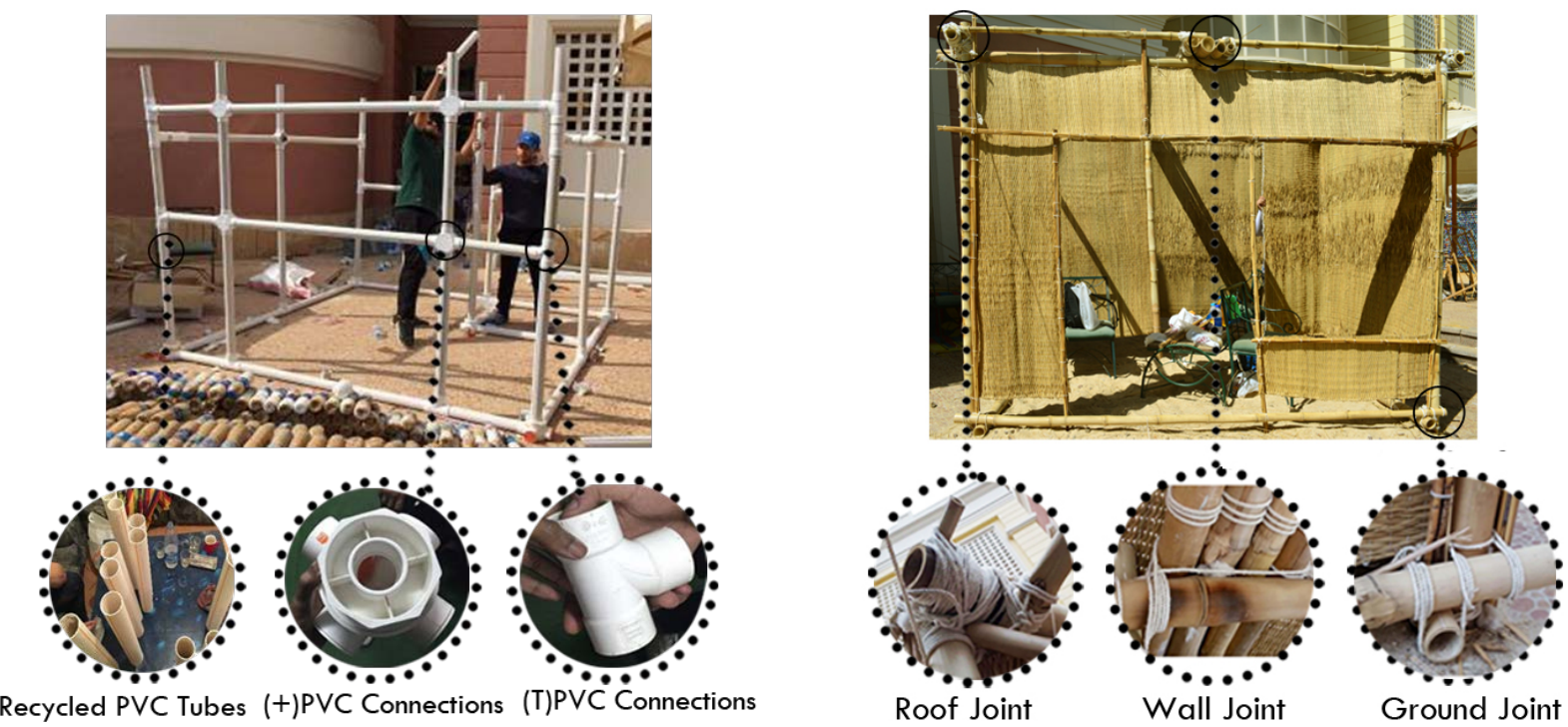

Figure 6: Different structure systems tested during the trial period (Source: Authors).

\section{Part three (internal and external jury evaluation)}

The students presented their final projects to five jury members (two external and three resident professors) who were invited to evaluate the two prototypes based on the following criteria: structural stability, suitability of materials and structure system, load resistance, form suitability and the innovation of the passive strategies applied. The jury members individually 
scored each of the above-mentioned criteria based on his/her own experience in such issues. That was important because it allowed students to receive feedback and comments on their work from evaluators who were experts in the field. Students in each group divided up the presentation between them to demonstrate their work and explain the processes, from design to construction. They took the jury on a tour inside each shelter to show them how to manage the adaptability of the structure to passive heating and cooling, natural daylight admittance and shading inside their shelters for indoor thermal comfort. They also showed how they had installed rain water collectors, how the waste water was managed, and how they had tried to design suitable pieces of furniture (a small sofa bed, a chair, a cupboard, a toilet seat and a kitchen sink) made from the same materials as those used in construction.
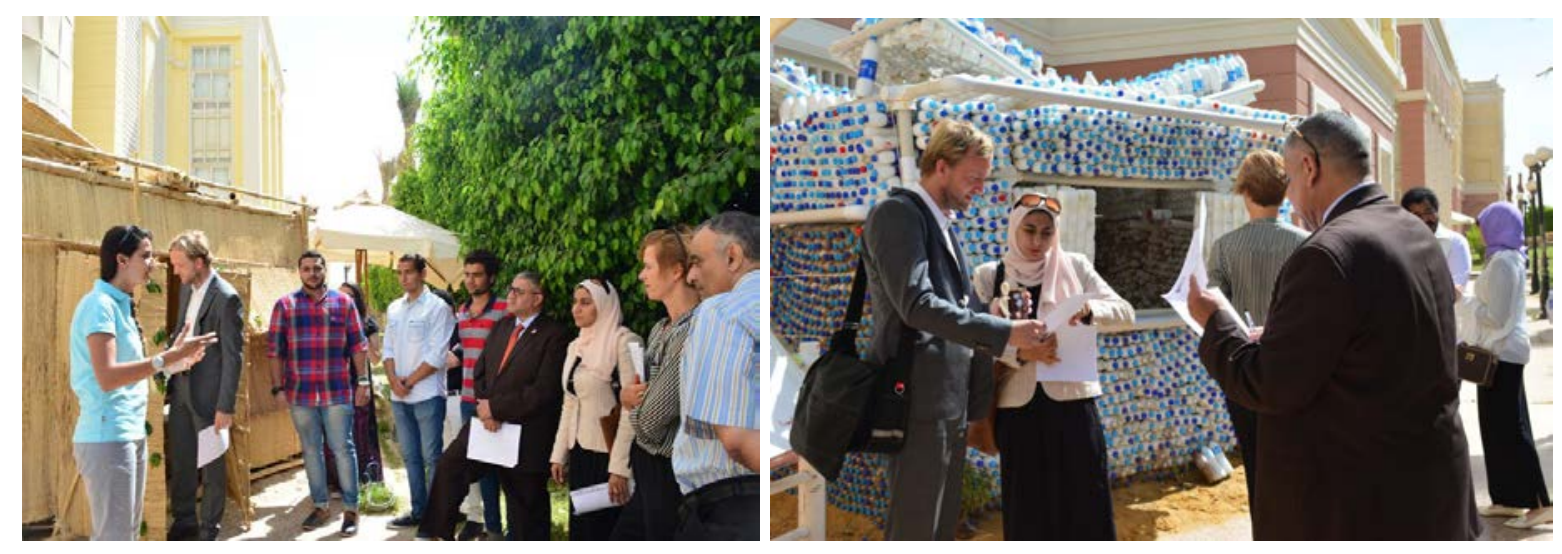

Figure 7: The final students' presentation and the jury evaluation (Source: Authors).

\section{RESULTS AND DISCUSSION}

\section{Phase One: Theoretical Base and Learning by Exploring}

The course began with an introduction to the energy crises and environmental problems experienced in contemporary building practices in Egypt. This was followed by a study of the problems and challenges inherent in the Egyptian energy efficiency building codes and rating systems. The introduction was given in relation to the situation with other countries in the Middle East and North African (MENA) region in comparison to the leading countries in Europe which are already successful in achieving their 2020 building energy efficiency targets. The shocking disparity of these facts was a tactic to open students' minds before the introduction of passive and energy efficient design concepts in relation not only to the climate but also to the cultural and social norms that affect a final building outcome. At first, the students were apprehensive about of the idea of building a full-scale physical model. They were accustomed to working with small-scale models with a maximum detailing of 1:50 scale. In addition, this was the first time they were expected to use real building materials and make their own decisions on which materials to choose and what building techniques to apply.

The field trip and off-campus workshop served as important learning tools for the first phase of the course. The students saw real examples of passive and eco-friendly design approaches using locally available materials such as clay, reeds, stone, and palm and acacia wood. They also saw how eco-cycle and sustainable cradle-to-cradle approaches could be 
applied. They met local NGOs who involve indigenous local communities in recycling, community development, organic farming and permaculture.
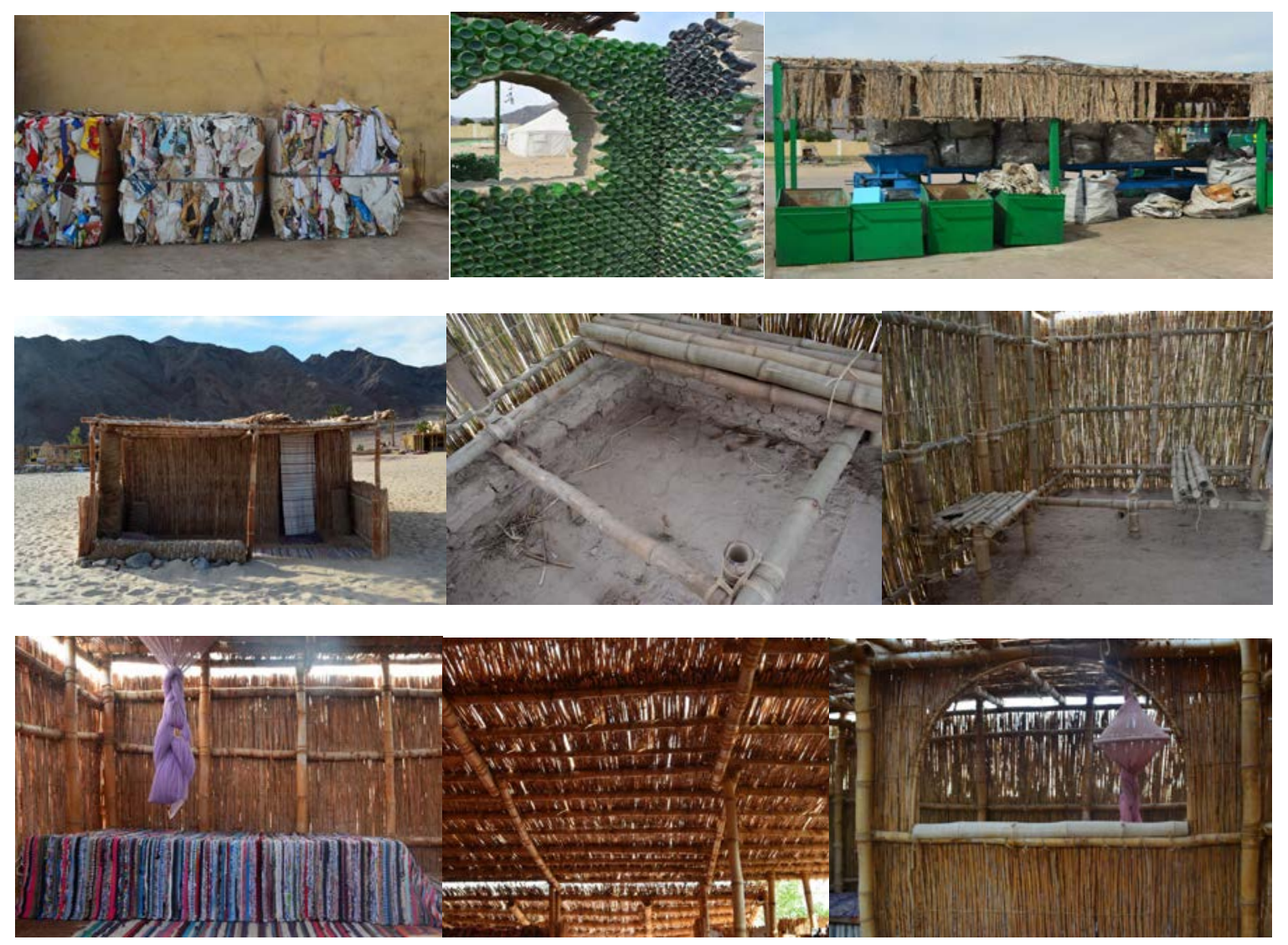

Figure 8: Different building typologies visited by the students during their field trip (Source: Authors).

By the end of the course, the students had succeeded in connecting the four pillars of sustainability: the economic, the social, the environmental and the cultural. In addition, during a one-day workshop on low-tech earth building techniques, the students were given the opportunity to test building techniques such as Adobe, Cob, Pise, and Wattle and Daub with their bare hands, as shown in Figure 9. This helped them to understand the properties and behaviour of materials in relation to the local physical and natural environment and how to connect the climate with the availability of natural resources in relation to human needs. The field trip and the hands-on workshop helped them to become more aware of how designbuild projects are intended to relate to the context of the city and the community, and respond to local considerations of climate and culture. 

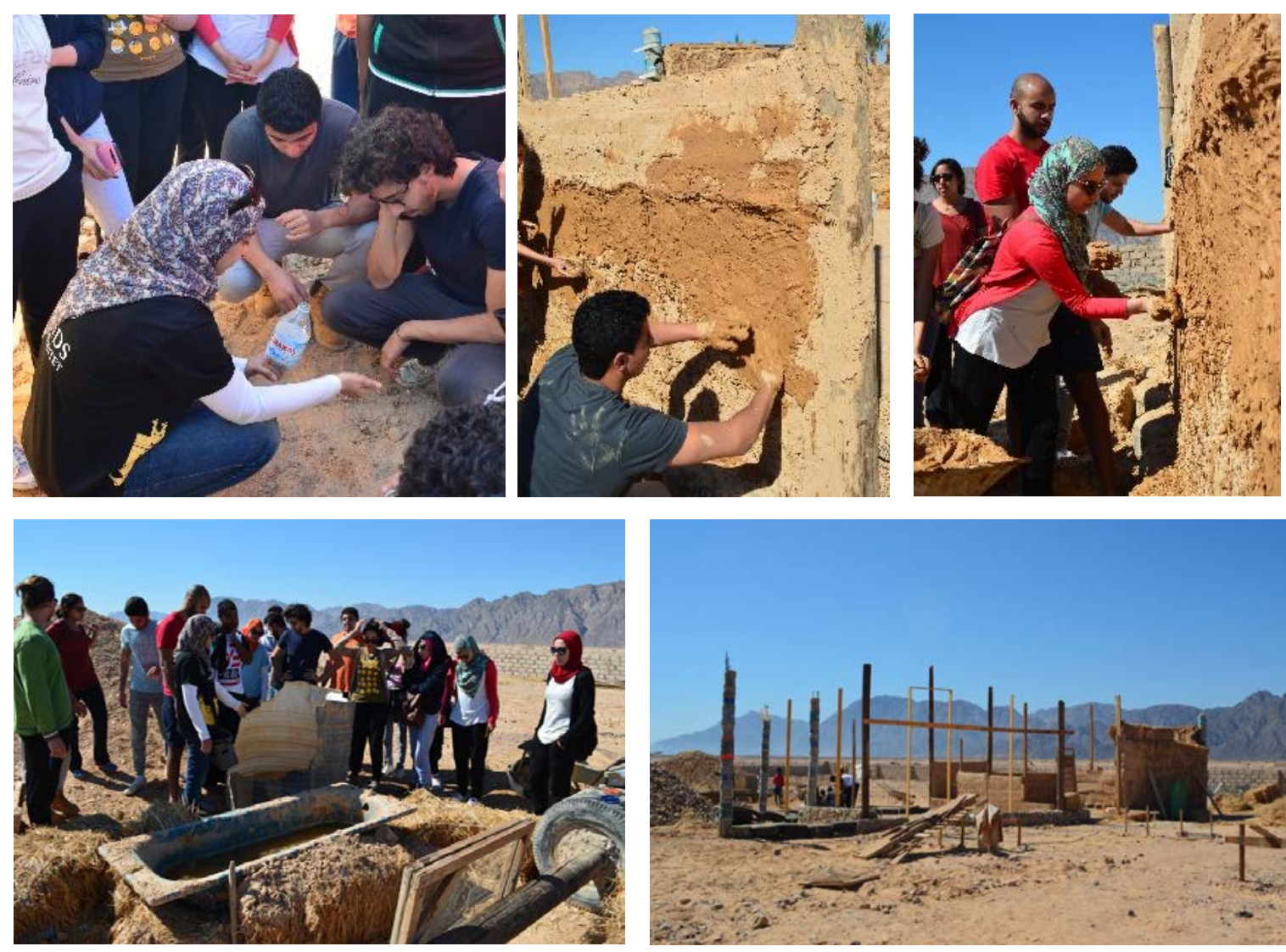

Figure 9: The hands-on workshop and testing of natural materials and techniques (Source: Authors).

\section{Phase Two: Feedback and Feedforward for Design Project Development}

The two groups of students came up with two different self-assembly and do-it-yourself proposals for a refugee shelter. Their designs reflected their understanding of the theory presented in the lectures, the field trips and the workshop, the literature search, and their onsite survey with current refugees in Egypt. They also made a field study of available feasible materials and the economics of supply. One group decided to use recyclable plastic bottles and plastic tubes with two different infills (sand and white foam) as a low-cost and low-tech material; the other group decided to use reeds and bamboo as biodegradable natural materials. Both groups developed several innovative passive solutions for cooling, heating and natural ventilation together with low-tech ideas for sanitation, water feeding and electric supply. Each group's design proposal was discussed on a weekly basis, and the development of the designs were based on comments and feedback. The students used simple software to simulate the likely energy performance of their proposals, and their designs were adjusted accordingly to meet passive house standards and the Egyptian code for energy efficiency in buildings. In this phase, the students developed both their skills and their understanding of the connection between the building users' needs, the design requirements, the building materials, the structure performance and economic feasibility along with the materials' thermal performance, indoor comfort standards and local climate. In this phase, they were also encouraged to think critically and comment on each other's 
proposals through peer review. The outcome of this phase was presented in the form of a manual sketch, computer 2D drawings, 3D models and 1:100 conceptual models.

\section{Phase Three: Physical Experimentation 1:1 Prototype and Evaluation}

Part one: During the five weeks of site work on campus, the students constructed their fullscale models. The students purchased the materials themselves and were responsible for storing them on site as well as managing the entire construction process. The location of the project allowed the students to take into consideration local conditions, for example, determining the availability of local materials to save on transportation costs. They started with small proof of concept test cells for the walls and roof structure and conducted several trial-and-error tests until they reached the desired results. At first the students were nervous about the performance of the final outcome compared to their design intentions and the simulation results. In this project exercise, this reaction was anticipated and was intended to give an understanding of the performance gaps that arise between a design concept and simulation in comparison to the real-as-built performance. It was evident from monitoring the results with them that the students were able to sense the gaps. They understood that the gaps could be variously ascribed to the accuracy of the simulation, local microclimate influence, occupancy patterns, users' age or gender and user behaviour. They also learned how to carry post occupancy evaluation and monitoring for different indoor building parameters such as temperature, humidity and $\mathrm{CO} 2$ concentrations. They also learned the differences in climate adaptive models and the different considerations to be taken into account in macro, mezzo and micro climate conditions. They gained more trust in alternative building materials and vernacular low-tech building methods. They also learned about alternative construction material behaviour and usability compared to conventional materials such as concrete and steel or industrial bricks. They developed several other skills, including the ability to make spontaneous decisions on site and to manage problems that were not considered when planning their projects; there were other skills too, such as time management, group leadership and work in teams, dividing tasks according to skills and interest. They developed the mental skill of translating architectural drawings into reality, and reality into drawings when they had to re-design connections that did not work as anticipated. They became used to consulting other experts in building construction, sanitation and plumbing fixtures and they learned more about other disciplines. The construction process and the final outcome is shown in figures 10 and 11. 


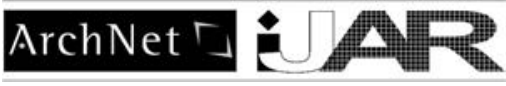

International Journal of Architectural Research

Marwa Dabaieh, Deena EI Mahdy, Dalya Maguid, Archnet-IJAR, Volume 12 - Issue 1 - March 2018 - (338-355) - Regular Section
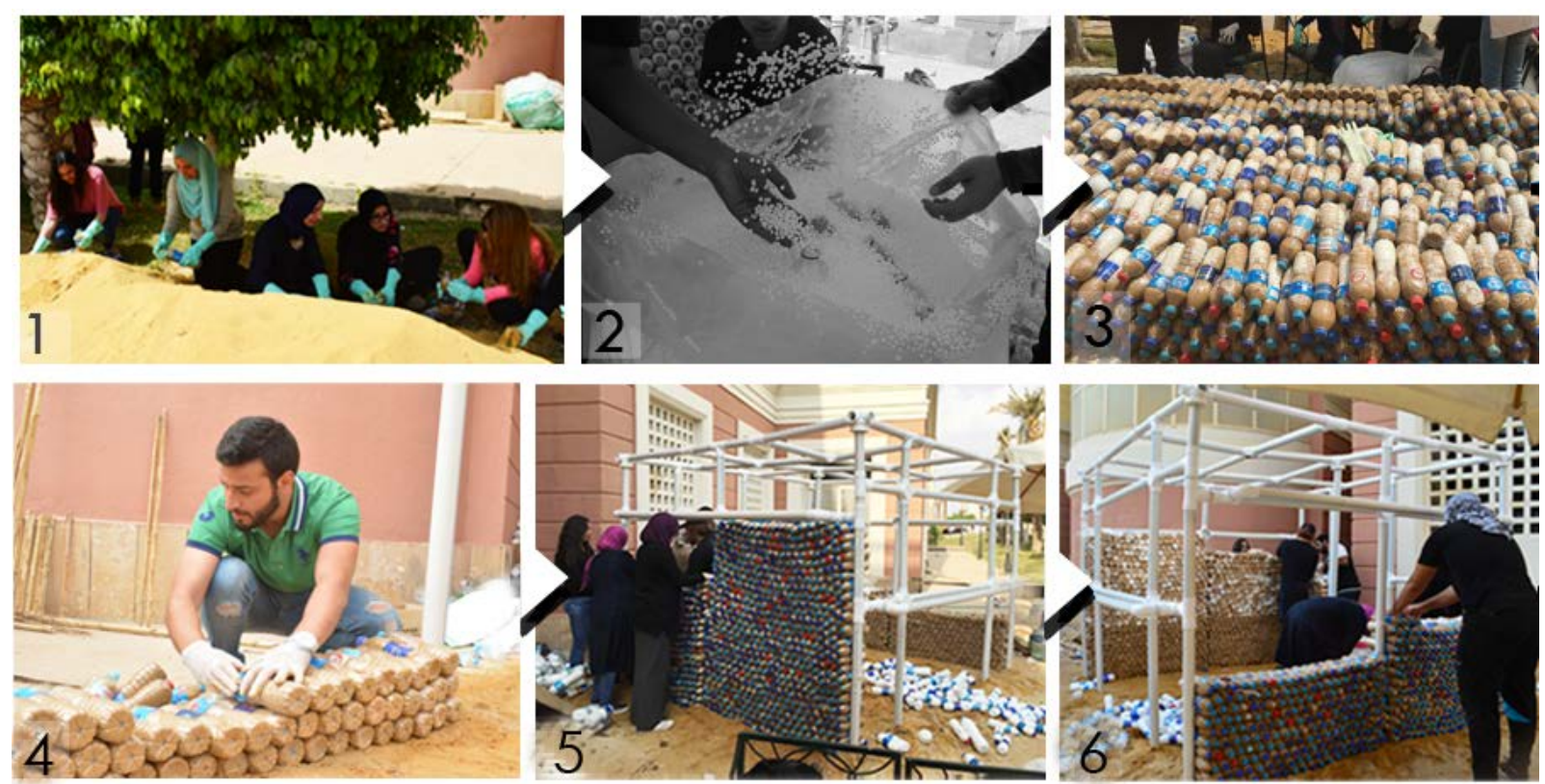

Figure 10: Construction process for group one using plastic bottles and plastic tubes (Source: Authors).
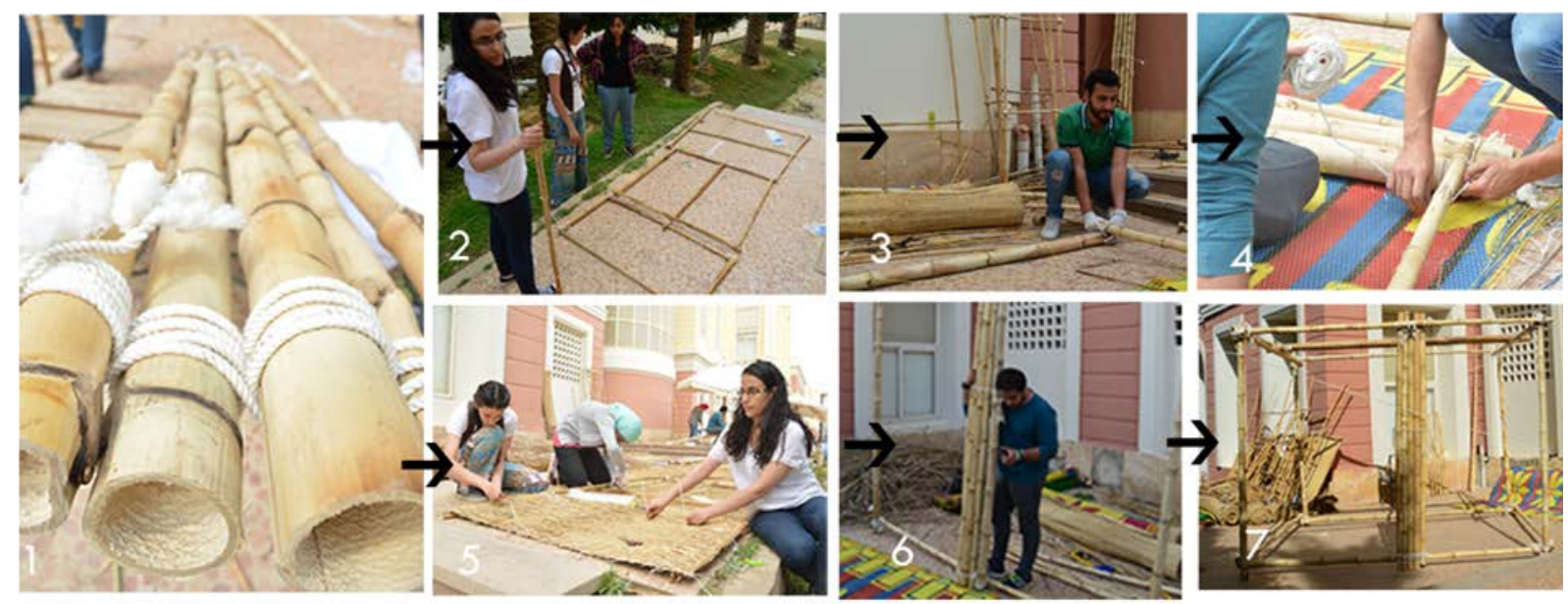

Figure 11: Construction process for group two using reeds and bamboo (Source: Authors).

Part two: The monitoring stage was conducted on 20th May 2016, and the result showed that the plastic bottles model performed better than the reeds and bamboo, with an average difference of $1.5^{\circ} \mathrm{C}$ for temperature and $2 \%$ for humidity. When it was $30^{\circ} \mathrm{C}$ outdoors, it was $26.5^{\circ} \mathrm{C}$ in the plastic bottles prototype and $28^{\circ} \mathrm{C}$ in the reeds and bamboo prototype. For comparison, the average indoor thermal comfort according to Egyptian standards EREC is $\left(22.2^{\circ} \mathrm{C}-25.6^{\circ} \mathrm{C}\right)(\mathrm{EREC}, 2008)$. The students understood the role of air tightness and infiltration as well as material thermal resistivity and performance. It was also useful for them to understand the performance of the passive strategies they applied, such as the proper orientation of their prototypes in relation to wind direction and sun, shade, thermal mass, thermal zoning, solar control, cross ventilation and the night-flush effect for cooling. They learned how to design, construct and install windows and doors to enhance building performance for ventilation and lighting together with other passive solutions such as wind catchers, solar chimney, light shelves and shading devices. The model-building exercise also

351

Copyright $@ 2018$ | Copyrights are granted to author(s), Archnet-IJAR, and Archnet @ MIT under the terms of the "CC-BY-NC-ND" License. 
further developed the students' skills, after several failures, in understanding structure performance and stability.

Part three: The students presented their ideas and models to the jury members and were evaluated according to the criteria mentioned in the methodology above. The jury commented that the students initially found themselves severely challenged in designing and constructing a $12 \mathrm{~m}^{2}$ shelter to satisfy all basic needs and to produce several design solutions for interior furniture and installations for a kitchenette and toilet using only one type of material. The many other skills they developed were noted by the jury, such as the connection between human needs, space zoning and material adaptations. The students were able to develop several effective solutions and structure design connections, using only simple tools such as ropes and wires, that were easy to construct and dismantle fast. Learning by doing and learning from previous mistakes helped the students to develop innovative solutions and enhanced their creative thinking abilities. The jury highlighted the fact that this experiment in building made the students more confident in communicating their design proposal to the jury as they had already proved its feasibility through monitoring and actual construction.

The process had equipped them with the essential skills to communicate with clients and their team of builders later on in real life. They developed a sense of the economic value of using natural materials in construction and during the building operation. Experience on the ground made clear the meaning of the supply chain for building material resources. The students had come to understand the health implications of using low impact construction methods in the short run, for example on indoor air quality; and then in the long run, at the building's end of life, with the effect of building waste on the environment. They are now equipped with an awareness of what is meant by embodied energy and embodied carbon in material extraction, construction and after demolition. The jury added that the students had developed communication skills using proper technical terms and terminology. They also learned to express themselves in a way that would enable them to become efficient architects able to communicate their green solutions confidently in the very competitive real estate market in Egypt and beyond. The final prototypes are shown in figure 12.
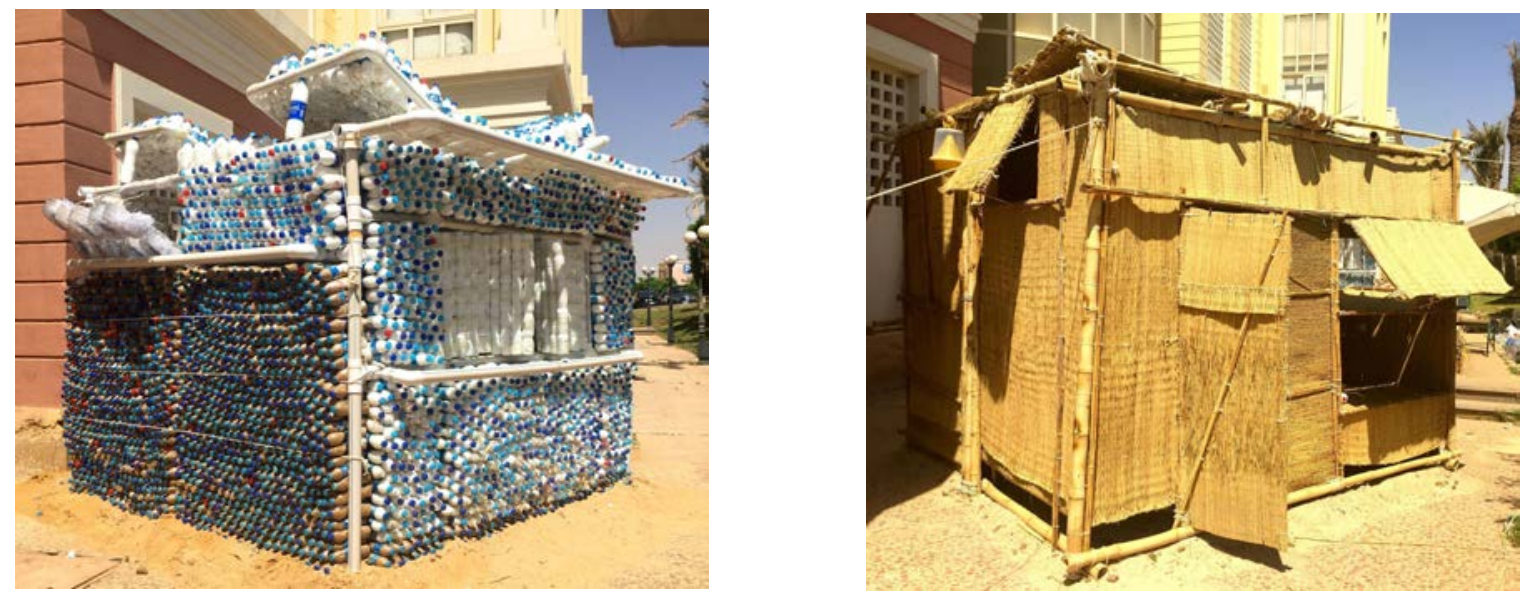

Figure 12: The final full-scale shelters (Source: Authors). 


\section{CONCLUSION}

Given the current energy crisis in Egypt, recent efforts by educators have been looking to incorporate energy efficiency and environmental awareness into architectural education. The experiential architectural course described in this paper was launched as a pilot teaching and learning experience in a living lab experimentation environment. The course pedagogy focused on learning by doing and guiding students to produce climatic responsive design in relation to local materials, culture and economy. The students were given the challenge to design a prototype that was low-cost, able to be self-assembled, quick to erect and dismantle (within a few hours), able to achieve adequate indoor thermal comfort, and equipped with basic necessities (water, sanitation and furniture) - all while acknowledging the local climatic context.

The results were assessed according to the elements of innovation in the design, the building cost calculations, the time a similar shelter would take to construct and dismantle, and the monitored results for indoor thermal performance. Some of this was familiar but the new factor was to teach students how to apply the knowledge gained in a practical manner through hands-on construction. This approach prepares students for the reality of architecture practice in Egypt, where design is rarely climate responsive, and more often than not, ill-adapted to the local climate. This teaching approach helped the students to understand how the actions they took turned drawings into a real building, in a manner similar to that of working with a real client. Additionally, the pilot allowed them to understand the physical building process and the value of testing out ideas, experimenting with concepts, and evaluating them in a real environment. The authors as the teaching team hope that the aims of this course will be developed further and move forwards from being simply a pilot course to becoming the norm in teaching environmental design. The pedagogical methodology followed in this study is applicable to other contexts and can be adjusted easily to different climatic and geographical zones with different material resources and vernacular building knowledge. In addition, the methodology can be applied in design studios and building construction courses alike. The different methodological phases followed for this pilot could be adopted wholesale or partially, tailored to the level of skill of the student's. It should be noted that the economic resources for running the course were limited, which should be no hindrance to other tutors wishing to try out a similar hands-on and dare-to-build experience.

\section{ACKNOWLEDGMENT}

The authors would like to thank the British University in Egypt for supporting the idea of teaching living lab on campus together with all the course students who were part of this experience.

\section{REFERENCES}

Al-Hagla, K.S. (2012). The role of design studio in shaping an architectural education for sustainable development: the case of Beirut Arab University. ArchNet-IJAR: International Journal of Architectural Research, 6(1), 23-41.

Altomonte, S. (2009). Environmental education for sustainable architecture. Review of European Studies, 1(2), p.12. 
Altomonte, S., Rutherford, P., \& Wilson, R. (2014). Mapping the way forward: education for sustainability in architecture and urban design. Corp. Soc. Responsib. Environ. Manage. 21, 143-154.

Beck, S. \& Mahony, M. (2017). The IPCC and the politics of anticipation. Nat. Clim. Chang. doi:10.1038/nclimate3264

Cole, L.B. (2014). The Teaching Green School Building: a framework for linking architecture and environmental education. Environ. Educ. Res. 20, 836-857.

Dabaieh, M. (2013). Energy efficient design strategies for contemporary vernacular buildings in Egypt. In: Correia, C.R. (Ed.), Vernacular Heritage and Earthen Architecture: Contributions for Sustainable Development. Portugal, pp. 599-604.

Dabaieh, M. (2015). More than Vernacular, first. ed. Media-Tryck, Lund

Dabaieh, M. \& Nour, H. (2013). Going green in architecture practice in Egypt: Passive design from training to practice. In the First Conference Of The Egyptian Affiliation Of International Building Performance Association Organization IBPSA-Egypt. Cairo, pp. 203-210.

Dabaieh, M., Lashin, M. \& Elbably, A. (2017). Going green in architectural education: An urban living lab experiment for a graduation green design studio in Saint Catherine, Egypt. Solar Energy, 144, pp.356-366.

Dessouky, N. (2016). Architecture and Urban Education in Egypt: Producing Designers that are Ready to Respond to the Social and Environmental Circumstances of the Egyptian Context. Procedia Environmental Sciences, 34, pp.401-410.

Egyptian Code for Improving the Efficiency of Energy Use in Buildings, Part 1: Residential Buildings (306/1). (2008).

Egyptian Energy Holding Company (EEHC). (2011). Egyptian Electricity Holding Company Annual Report 2010/2011.

Farahat, B.I. (2011). Architectural Education Future Experience in Designing a New Curriculum for Undergraduate University Education in Architecture. In Proceedings of EDULEARN 11 Conference. Barcelona, pp. 743-757.

Gaber, T. \& Al-lbrashy, M. (2010). Design with the senses and for the senses: an alternative teaching model for design studio. Archnet-IJAR: International Journal of Architectural Research, 4 (23),359-375.

Gucyeter, B. (2016). The Place of Sustainability in Architectural Education: Discussion and Suggestions. Athens Journal of Architecture, 2(3), pp.237-255.

Guzowski, M., 2010. Towards Zero-Energy Architecture: New Solar Design. Laurence King Publishing, London, U.K.

Hoffman, P.J. (2009). Making the change to sustainability: building green builds a better education. Tech. Connect. Educ. Careers 84, 16-21.

IPCC. (2007). Climate Change 2007: The Physical Science Basis. Contribution of Working Group I to the Fourth Assessment Report of the Intergovernmental Panel on Climate Change, Cambridge: Cambridge University Press.

Juan, Y.-K. \& Chao, T.-W. (2015). Game-based learning for green building education. Sustainability 7 , 5592-5608.

Khasreen, M.M., Banfill, P.F. \& Menzies, G.F. (2009). Life-cycle assessment and the environmental impact of buildings: a review. Sustainability, 1(3), pp.674-701.

La Roche, P. (2017). Carbon-neutral architectural design. Taylor \& Francis, Boca Raton.

Lee, Y.-L. \& Huang, F.-H. (2011). Recommender system architecture for adaptive green marketing. Expert Syst. Appl. 38, 9696-9703. 
Lenzholzer, S. \& Brown, R.D. (2013). Climate-responsive landscape architecture design education. J. Clean. Prod. 61, 89-99.

Lidgren, A., Rodhe, H. \& Huisingh, D. (2006). A systemic approach to incorporate sustainability into university courses and curricula. Journal of Cleaner Production, 14(9-11), pp.797-809.

RCREEE. (2013). Energy Efficiency Country Profile. Cairo.

Reinhart, C.F., Dogan, T., Ibarra, D. \& Samuelson, H.W. (2012). Learning by playing -teaching energy simulation as a game. J. Build. Perform. Simul. 5, 359-368.

Salama, A.M. (2009). Transformative Pedagogy in Architecture and Urbanism. Solingen: UmbauVerlag.

Salama, A.M. (2010). Delivering Theory Courses in Architecture: Inquiry-Based, Active, and Experiential Learning Integrated. Archnet-IJAR: International Journal of Architectural Research, 4(2-3), pp.278-295.

Salama, A.M. (2015). Spatial Design Education: New Directions for Pedagogy in Architecture and Beyond. Surrey: Ashgate Publishing Ltd.

Salama, A.M. \& Amir, A. (2005). Paradigmatic trends in Arab architectural education: impacts and challenges. World Congress of Architects: The International Union of Architects-UIA: Istanbul. Turkey.

Samir EISawy, M. \& Safey EIDeen, H. (2014). Towards a methodology for incorporating sustainability into architectural curricula. In: EDULEARN14 Proceedings. 6th International Conference on Education and New Learning Technologies. IATED,Barcelona, Spain, pp. 3601-3614.

Sewilam, H., McCormack, O., Mader, M. \& Abdel Raouf, M. (2015). Introducing education for sustainable development into Egyptian schools. Environ. Dev. Sustain. 17, 221-238.

Shaaban, W.A. \& Badr, M. (2013). Applying Sustainability Principles on Architectural Design Concepts in Egypt to Enhance Building Performance. In Building Simulation Cairo 2013 - Towards Sustainable \& Green Built Environment. Cairo, pp. 1-13.

Taleghani, M., Ansari, H.R. \& Jennings, P. (2010). Renewable energy education for architects: lessons from developed and developing countries. Int. J. Sustain.Energy 29, 105-115.

Taleghani, M., Ansari, H.R. \& Jennings, P. (2011). Sustainability in architectural education: a comparison of Iran and Australia. Renew. Energy An Int. J. 36, 2021-2025.

Vargas, B.A. (2016). The relationship between architecture and Education for Sustainable Development (ESD). Space as a reactive factor within the pedagogical model. Bordon 68, 145 163. 